\title{
The Function Of Gendang As Musical Performance In A Marriage Ceremony In The Karo Society
}

\author{
Kumalo Tarigan, \\ Universitas Sumatera Utara \\ kumtar@yahoo.com
}

\begin{abstract}
In the Karo society the gendang performances at a the marriage ceremony is very important. So important that there is no more marriage ceremony without it. Observation and analysis show that legalized marriages is not with the gendang performances, but are very important to support on the three parts of a series of events at the marriage ceremony. First, accompanying sukut or people who perform the ceremony to enter the ceremony place with their kinsfolk both the groom's family and the bride's family. Second, to accompany the bride and groom to dance and sing alternately. Third, accompanying sukut with their kinsfolk dancing together while delivering speech acts, both the groom's family and the bride's family. The most important functions of gendang performance are: i) as one of the norms in a marriage ceremony, ii) as a physical reaction, iii) as a customary communication, and iv) as community integration.
\end{abstract}

Key word: function, gendang, marriage ceremony, Karo society

\section{Introduction}

Karo is one of the ethnic groups living in the province of North Sumatra who in their circle of life performs many ceremonies, not only for the benefit of the general public but also for the benefit of individuals. Both the ceremonies are performed for the benefit of the general public or individually always attended by many people. This fact is due to the Karo people who pay attention to kinship in great detail, not only based on birth but also from marriage that regularly follow to their customary. The ceremonies for the benefit of the general public such as kerja tahun or an annual party, ngeleboh wari udan or the calling for a rainy day, and ngarkari or the cleaning a village from the evil influences. The ceremony for individual interests that can be seen based on their type, level and kind. There are three types of ceremonies in the Karo community, namely kerja meriah ukur or happiness ceremony, kerja erceda ate or misfortune ceremony and kerja nambar-nambari or treatment ceremony. According to the level of all the ceremonies in the Karo society can be divided into three, namely singuda or simple, sientengah or medium and sintua or large. While based on the kinds of ceremony, i.e : maba anak ku lau or the bringing the children to the baths, cabur bulung or the practicing customary marriage to the children, raleng tendi or the calling for human spirits, erpangir ku lau or the self-purification, erdemu bayu or the marriage 
ceremony, nengget or the surprising, mesur-mesuri or the giving especial food, mengket rumah mbaru the entering a new home, petampe jinujung or the authorizing the spirit to be a guide, ngari-ngari or the thanksgiving for healing or safety, mere ciken or the giving a stick, mereken pangan entabeh or the giving good food, nurun the funerals, ngangkat tulan-tulan or the lifting bones.

\section{The Custom and Society of Karo}

The Karo society adhere to the clan system called merga. There are five clans in Karo, i.e.: ginting, karo-karo, perangin-angin, sembiring, and tarigan. Each clan has branches, all branches of the five clans are 73. With the existence of the clan system, kinship relations are greatly influenced. The same clan is considered. There are three clans inherited which are very important to every Karo person. First, the clan inherited from the father, called merga for male and beru for female. Second, the the clan inherited from the mother, called bere-bere. Third, the clan inherited by grandmother (mother's mother) called кетри. The three clans inherited above can be a family name or surnames. In the Karo tradition the kinsfolk are so important, because with them there the various ceremony can take place properly. According to Karo's customary the kinsfolk are divided into three groups, namely, tegun senina or all of the father's brothers families, tegun kalimbubu or all of the mother's brothers families, and tegun anakberu all of the father's sisters families. These three groups must be have both the groom's family and the bride's family. The person whose the arranges and leads the marriage ceremony is one of the groom's anakberu, and one of the brides' anakberu, called the anakberu si ngerana or anakberu spokesperson. Tegun senina consists of six groups, namely: 1) senina, means same clan and clan branches, 2) sembuyak, means same clan and different clan branches, 3) sipemeren means the mother's sisters or same clan of his mother, 4. siparibanen, means the wife's sister or same clan of his wife, 5) sepengalon, means the relationship of two or several people who have the same their anakberu. 6) sedalanen, means the relationship between two or several people who have the same their kalimbubu. Tegun kalimbubu, in the context of the marriage ceremony. there are difference between the groom's kalimbubu and the bride's kalimbubu Tegun kalimbubu of groom's family there are threes, namely 1) kalimbubu si ngalo ulu emas means the brother of mother's groom, 2) kalimbubu si ngalo ciken-ciken or puang kalimbubu means kalimbubu of the brother of mother's groom or kalimbubu of kalimbubu, and 3) puang ni puang means the kalimbubu of puang kalimbubu of groom's family. Tegun kalimbubu of 
bride's family there are four, namely 1) kalimbubu si ngalo bere-bere means the brother of mother's bride, 2) kalimbubu si ngalo perkempun or puang kalimbubu means the kalimbubu of brother of mother's bride. 3) kalimbubu si ngalo perbibin means the sister of mother's bride, 4) puang ni puang means kalimbubu of puang kalimbubu of bride's family.Tegun anakberu, consists of five groups, 1) anakberu means all of the father's sisters families, 2) anakberu menteri means anakberu than anakberu. 3) anakberu pengapit is anakberu than anakberu menteri, 4) anakberu singikuri means anakberu follow the father's sisters families, 5) anakberu sipemeren, means the relationship anakberu happens because their mother is siblings. All the kinsfolk mentioned above have a role in the marriage ceremony. In the Karo society's view there are three roles of kinsfolk, namely ndungi or making it complete, petunggungken or making it appropriate and pehagaken or making it great.

\subsection{The Marriage Ceremonies According to the Karo's Tradition}

According Tarigan (2017) that there are nine events that run coherently in a marriage ceremony in the Karo society, but I saw there are ten real facts, i.e.:The party carrying out the wedding ceremony entering the ceremony site called galo-ngalo sukut,Breakfast or ngukati, The dressed in Karo tradition all of parents and bride and groom called rose, The tribe of kinsfolk the dowry payment agreement called ertembe-tembe, The transfer of the bride price from the groom to the bride called ersukat emas, The notification of the person responsible for the marriage ceremony called sijalapen, Taking the bride by the groom or ngelegi beru,The paying customary debt to the kalimbubu (the family of mother's brother) of the groom called enggalari ulu emas, The bride and groom dance while singing alternately called adu pengantin, The implementing speech acts or ngerana

\subsection{The Gendang Performance}

Actually $\mathrm{n}$ the Karo society 'gendang' has several meanings. It can mean as musical composition, musical instrument name, song and musical performance. In this paper it means as a musical performance. The composition of the Karo traditional music can be known from the music produced of the gendang sarune. The gendang sarune is a Karo traditional music ensemble whose musical instrument consists of a sarune (double reeds conical aerophone), three drums which are grouped into two parts, and two gongs. Three drums (single head conical drum) which are grouped into two parts, namly gendang singanaki dan gendang singindungi. In the composition musical of the gendang sarune, there is a melody, the rhythm of the drum and 
the sounds of gongs. Melody is able to be produced by sarune and vocals. The rhythm is produced by the Karo's drum. Likewise gongs, in Karo music, there are two gongs, the big one and the small one, both produces a colotomic sound. Since the beginning of 1991 keyboard musical instruments began to influence the Karo music tradition. At that time the kyboard was used to increase the rhythmic strength of the drum. It adds excitement to people who dance and watch. Thus many people get stimulation to dance. Not long after that, the chord element was used to increase the strength of the colotomic sound of the gong. The element of melody was created from a keyboard musical instrument, which in the end the gendang Karo as a musical performance could have been realized with a single keyboard in early 1992 . Since then the development of the gendang kibod in the Karo society has been very rapid.In marriage ceremonies the music used is the gendang kibot or to use a keyboard instrument. Today in Karo musical culture the gendang kibot is the same as the gendang sarune or Karo traditional music ensemble. The gendang kibot has been programmed to be able to imitate the gendang or Karo traditional music composition. In the composition regarding the melody.Karo music generally does not recognize tonality, therefore the kibot melody and singing melodies run on their own. Indeed, in the concept of Karo music the melody of the vocals and the melody of the musical instrument must be the same. Although in reality the two are really different, they are still considered the same. This melody is not permanent, in the sense that it can change according to the style of the person who sings or plays it. In the concept of Karo music, playing music is ranggut or fused. On that part the kibot melody continues along with the speech acts or singing melody.This shows that melodic tolerance in Karo music is very large.

\subsection{The Musical Composition and Function of Gendang}

Although ten events in a series of marriage ceremonies only three of them require gendang accompaniment. First, to accompany paraded the person whose carrying out the marriage ceremony entering the ceremony site. This happened four times, in the beginning, the groom with his parents and tegun senina enter the ceremony site where they are welcomed by their anakberu. The next, the groom's kalimbubu enter the ceremony site where they are welcomed by sukut. Forward, the bride with his parents and tegun senina enter the ceremony site where they are welcomed by their anakberu. Finally, the bride kalimbubu enter the ceremony site where they are welcomed by sukut. Second, to accompany the bride and groom dance while singing alternately. This happen only once, although two songs for the groom and two songs for the bride. But to take the grooms and bride to dance and sing alternately, all 
the participants of the ceremony initially joined in together dancing. Not so long after that the leader of the ceremony will direct to all the kinsfolk to stop dancing so that only the groom and bride are left behind.Third, to accompany speech acts or ngerana. This happened seven times, in the beginning, the groom and his parents and all tegun senina dance together and speech acts alternately according to the direction of the anakberu si ngerana of the groom's family as one of the ceremonial leaders. The next, the bride and his parents and all tegun senina dance together and speech acts alternately according to the direction of the anakberu singerana of the bride's family. After that, the bride and groom and their parents with local government and their colleagues, acquaintances, associates dance together and speech acts alternately according to the direction of the anakberu si ngerana of the groom's family. After that next, the groom and his parents and all tegun kaimbubu dance together and speech acts alternately according to the direction of the anakberu si ngerana of the groom's family. Afterwards, the bride and his parents and all tegun kalimbubu dance together and speech acts alternately according to the direction of the anakberu si ngerana of the bride's family. Then, the bride and his parents and all tegun anakberu dance together and speech acts alternately according to the direction of the anakberu singerana of the bride's family Finally, the groom and his parents and all tegun senina dance together and speech acts alternately according to the direction of the anakberu singerana of the bride's family.

According to the kibot players, the musical compositions that are played to accompany them to dance while walking to in entering the place of the ceremony is cacak odak-odak. Cacak odak-odak can be seen as figure 1 .

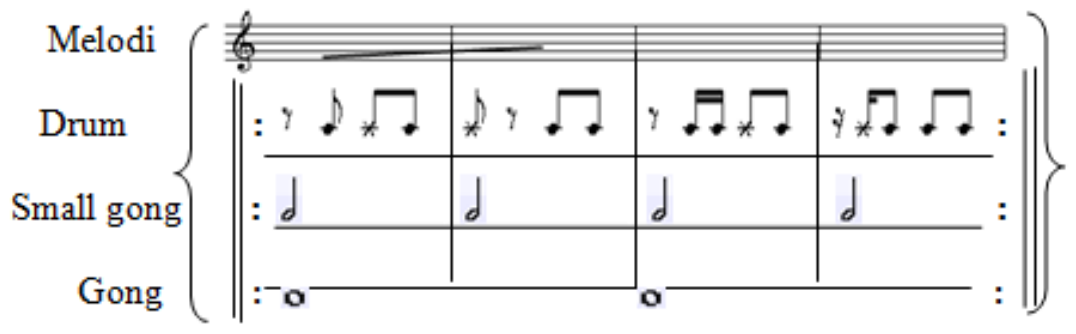

Figure 1. Cacak odak-odak

When accompanying the bride and groom dance while singing alternately, besides cakcak odak-odak there is another one called cakcak patam-patam. Cacak odak-odak can be seen as Figure 2. 


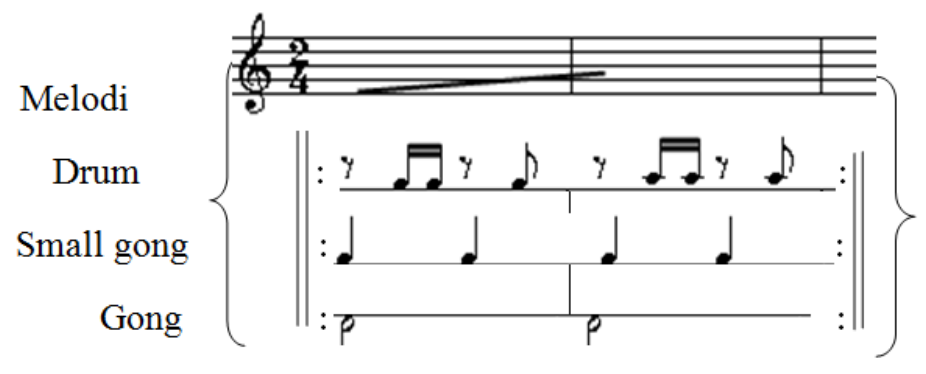

Figure 2. Cacak odak-odak

While the composition of the music that accompanies the speech act is different from both previous musical composition, called cakcat simalungen rayat, like Figure 3.

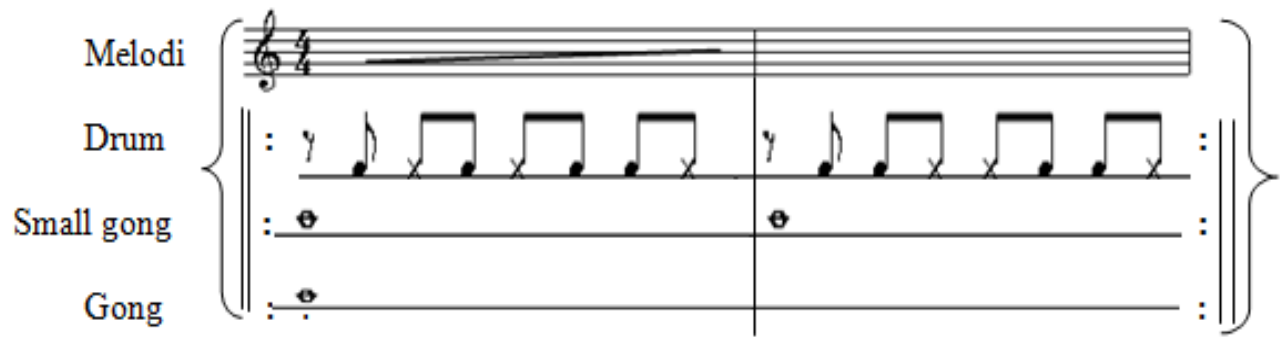

Figure 2. Cacak odak-odak

To find the function of the gendang as music in marriage ceremonies in the Karo society must pay attention to the three events that require the musical performance. Although there are four shows done basically the same. The event began with all sukut parties from the family of groom or bride standing about ten meters in front of the entrance of the jambur which is the place of ceremony. They are moved into the jambur as far as a fifteen meters. In this case the function of gendang is to accompany them to dance to while walking. Thus however in the event ngalo-ngalo sukut the function of music as a physical reaction. Furthermore, things are more or less the same as the adu pengantin ( the bride and groom dance), the music is also used to accompany them to dance while singing alternately. Thus in this section also the function of music is for physical reaction.It is very different from the event of ngerana or speech act, the gendang is useful to accompany the party performing the ceremony with their kinsfolk dancing while delivering the speech act. In this case the gendang or music functions as a norms in the marriage ceremony. 
Besides that, in this case, the functions of gendang also as a communication and as community integration.Based on this description it can be said that the most important functions of gendang are: i) as a physical reaction, ii) as a norms in a marriage ceremony, iii) as a communication norms, and iv) as community integration.

\section{Conclusion}

Right now the performance of gendang is an absolute at a marriage ceremony at the Karo society. There is no longer a marriage ceremony without the performance of gendang. Really the community realizes that it is not the gendang that makes a marriage ceremony valid but with the gendang being believed the ceremony can take place very well. Gendang can reveal the deepest sense of humanity that can no longer be expressed by words or other actions.

\section{Acknowledgment}

The research was funded by the USU in accordance with the USU Talent Research Implementation Contract 2019 Number: 4167 / UN5.1.R / RPM / 2019, dated April 1, 2019

\section{Bibliography}

Nettl, Bruno. 2019. Teori Dan Metode Dalam Etnomusikologi, Jokyakarta: Penerbit Ombak.

Tarigan, Kumalo. 2017. Contents of Ritual Chanting "Pemasu-Masun" in Marriage Ceremony in Karo Society, In the "American International Journal of Contemporary Research" Vol.7 No. 4; December 2017 ISSN 2162-139X (Print), ISSN 2162- 142X (Online)

Tarigan, Kumalo. 2018. Canta Ritual Karo Di Sumatera Utara Mengikut Adat Enggeluh (Peraturan Kehidupan), Doctoral Dissertation, Pulau Pinang: Universiti Sains Malaysia. 